\title{
DETERMINATION OF ZINC OXIDE NANOPARTICLES TOXICITY IN ROOT GROWTH IN WHEAT (TRITICUM AESTIVUM L.) SEEDLINGS
}

\author{
Meppaloor G. Prakash and Ill Min ChunG* \\ Department of Applied Biosciences, School of Life and Environmental Sciences, \\ Konkuk University, Seoul, South Korea
}

(Received: January 8, 2016; accepted: February 15, 2016)

\begin{abstract}
The effect of zinc oxide nanoparticles (ZnONPs) was studied in wheat (Triticum aestivum L.) seedlings under in vitro exposure conditions. To avoid precipitation of nanoparticles, the seedlings were grown in half strength semisolid Murashige and Skoog medium containing 0, 50, 100, 200, 400 and $500 \mathrm{mg} \mathrm{L}^{-1}$ of $\mathrm{ZnONPs}$. Analysis of zinc ( $\mathrm{Zn}$ ) content showed significant increase in roots. In vivo detection using fluorescent probe Zynpyr-1 indicated accumulation of $\mathrm{Zn}$ in primary and lateral root tips. All concentrations of ZnONPs significantly reduced root growth. However, significant decrease in shoot growth was observed only after exposure to 400 and $500 \mathrm{mg} \mathrm{L}^{-1}$ of ZnONPs. The reactive oxygen species and lipid peroxidation levels significantly increased in roots. Significant increase in cell-wall bound peroxidase activity was observed after exposure to $500 \mathrm{mg} \mathrm{L}^{-1}$ of ZnONPs. Histochemical staining with phloroglucinol-HCl showed lignification of root cells upon exposure to $500 \mathrm{mg} \mathrm{L}^{-1}$ of ZnONPs. Treatment with propidium iodide indicated loss of cell viability in root tips of wheat seedlings. These results suggest that redox imbalances, lignification and cell death has resulted in reduction of root growth in wheat seedlings exposed to $\mathrm{ZnONPs}$ nanoparticles.
\end{abstract}

Keywords: Triticum aestivum - zinc oxide nanoparticles - root growth - reactive oxygen species - lignin

\section{INTRODUCTION}

The enhanced or altered physico-chemical properties of engineered nanoparticles (ENPs) as compared to the bulk materials have resulted in their widespread use in several consumer, cosmetic, medical, pharmaceutical and agriculture applications $[11,19]$. However, the release of ENPs from these products to the environment could result in environmental contamination by creating nano-waste which can create unknown potential ecotoxicological problems [2, 5, 34]. Moreover, the continuous production, utilization and subsequent release of ENPs will lead to their increase in environmental concentrations [34].

Zinc $(\mathrm{Zn})$ is an essential micronutrient required for growth and development of plants and is involved in many physiological processes such as photosynthesis and

*Corresponding author; e-mail address: illchung@konkuk.ac.kr 
biosynthesis of plant growth factors [4]. The harmful effect of excess Zn, such as changes in nutrient homeostasis, leaf chlorosis and inhibition of photosynthesis has been reported from previous studies [24]. Zinc oxide nanoparticles (ZnONPs) are among the most widely used ENPs in optical, semiconductors, magnetic and gas sensing, pigments, sunscreens, food additives etc. [11]. As a result of their increased use in agricultural related applications and through the application of sewage sludges, the ZnONPs could get accumulated in agricultural fields and contaminate food crops [21].

As plants are the essential base component of the ecosystems, and being sessile organisms, they play an important role to assess the effects of ENPs in the environment $[22,34]$. In plants, root growth is characterized by high metabolic activity and alteration or inhibition occurs as a result of abiotic stresses such as exposure to excess trace elements [24]. Therefore, root growth has been considered as simple and sensitive test to investigate the effects of metal stress [24]. Moreover, different types of plant species need to be examined to clarify nanoparticle uptake by plant and the subsequent fate within food chains [18]. The toxic effect of ZnONPs has not been studied in detail in wheat, an economically important food crop. Therefore, the aim of the present study is to understand the toxic effects of ZnONPs in roots of an economically important food crop, wheat (Triticum aestivum L.).

\section{MATERIALS AND METHODS}

\section{Characterization of nanoparticles}

ZnONPs were purchased from Sigma-Aldrich (St. Louis, MO, USA). The morphology of the ZnONPs was examined under transmission electron microscope (TEM; LIBRA 120, Carl Zeiss, Germany) after drop coating and drying on carbon-coated TEM grids (Tedpella Inc., USA).

\section{Plant material and growth conditions}

The seeds were surface sterilized for 15 min using sodium hypochlorite $(10 \% \mathrm{v} / \mathrm{v})$ and washed three times with sterilized deionized water and germinated by placing on two layers of wet whatman\#1 paper in petri dishes (SPL Life Sciences, South Korea) under $25^{\circ} \mathrm{C}$ in the dark for $48 \mathrm{~h}$. Ten germinated seeds, with $1 \mathrm{~mm}$ root length, were transferred to plant growth vessels (SPL Life Sciences, South Korea) containing half strength Murashige and Skoog medium [pH 5.7; $20 \mathrm{~g} \mathrm{~L}^{-1}$ sucrose; $5 \mathrm{~g} \mathrm{~L}^{-1}$ agar (Duchefa Biochemie, The Netherlands)]. Different concentrations of ZnONPs (0, 50, $100,200,400$ and $500 \mathrm{mg} \mathrm{L}^{-1}$ ) were added to the medium and mixed well by vortexing before pouring into the growth vessels. For $\mathrm{Zn}$ ion treatment, the seedlings were grown in the presence of 8 and $12 \mathrm{mg} \mathrm{L}^{-1}$ of $\mathrm{ZnSO}_{4}$. The cultures were incubated under growth chamber (Hanbaek Scientific Co., South Korea) conditions with a light 
intensity of $100 \mathrm{~m} \mathrm{E} \mathrm{m}^{-2}$ with $16 \pm 8 \mathrm{~h}$ photoperiod at $26 \pm 2{ }^{\circ} \mathrm{C}$. Each of the treatment contained five replications with ten seedlings in each growth vessel and the seedlings were harvested after 7 days. The experiment was repeated four times.

\section{Analysis of zinc content}

$\mathrm{Zn}$ content in root samples from the control, low $\left(50 \mathrm{mg} \mathrm{L}^{-1}\right)$, medium $\left(200 \mathrm{mg} \mathrm{L}^{-1}\right)$ and high (500 $\mathrm{mg} \mathrm{L}^{-1}$ ) concentrations of ZnONPs treated samples was determined using inductively coupled plasma atomic emission spectroscopy (ICP-AES; Ultrace, Jobin Yvon, France). The roots were washed with deionized water and dried at $75^{\circ} \mathrm{C}$ for $48 \mathrm{~h}$ in a drying oven (Model: HB-503 LF; Hanbaek Company; South Korea). Fifty milligrams (dry weight, DW) of the dried root samples were digested with concentrated $\mathrm{HNO}_{3}$ in a dry bath (Model: JBI-01; JMC R\&D Inc., Daejeon, South Korea) at $115^{\circ} \mathrm{C}$ for $3 \mathrm{~h}$. After digestion of samples, the volume was adjusted to $20 \mathrm{~mL}$ with deionized water. The samples were filtered using $0.2 \mu \mathrm{m}$ nylon filters (Chromedisc $\mathbb{}$ ) syringe filter, Seoul, South Korea).

\section{Detection of zinc accumulation using Zinpyr-1 treatment}

Detection of $\mathrm{Zn}$ accumulation in roots of $\mathrm{ZnONPs}$ and $\mathrm{Zn}$ ion (8 and $12 \mathrm{mg} \mathrm{L}^{-1}$ ) treated seedlings was done with Zinpyr-1 treatment as described by Song et al. [33] after washing alternately with deionized water and in $10 \mathrm{mM}$ ethylenediaminetetraacetic acid (EDTA). Images were taken using the fluorescent microscope and associated software (BX61-32 FDIC, Olympus, Japan).

\section{Physiological analysis}

$\mathrm{H}_{2} \mathrm{O}_{2}$ content in roots was determined as described by Brennan and Frenkel [3] using $200 \mathrm{mg}$ of plant tissues. Lipid peroxidation in roots was determined according to Heath and Paker [12]. The cell wall peroxidase $(P O D)$ activity was determined according to the protocol of $\mathrm{Li}$ et al. [16].

\section{Detection of reactive oxygen species, cell death and lignin}

To detect the superoxide generation, fresh roots were treated with fluorescent probe dihydroethidium (DHE) [13]. For detection of $\mathrm{H}_{2} \mathrm{O}_{2}$ generation in roots, the fluorescent probe, 3'-( $p$-hydroxyphenyl) fluorescein (HPF) (Invitrogen, USA) was used [14]. The cell death in roots was determined using propidium iodide (PI) treatment with minor modifications from the method of Kwon et al. [15]. For the in vivo detection of lignification of roots, fresh roots were incubated in $1 \%(\mathrm{w} / \mathrm{v})$ phloro- 
glucinol-HCl solution for 5 min as described by Rogers et al. [25]. The DHE, HPF and PI treated roots were photographed with a fluorescence microscope and associated software (BX61-32 FDIC, Olympus, Japan). The phloroglucinol treated roots were photographed using a Nikon 80i (Nikon, Japan) microscope and related software.

\section{Data analysis}

Data were analyzed using one-way ANOVA test with the statistical software SPSS12.0 KO (SPSS Inc., IL, USA). Dunnett's post-doc test was done to determine the effect of different exposures on tested parameters. The data were expressed as mean \pm standard error (SE). A probability level of $p<0.05$ was considered significant.

\section{RESULTS}

\section{Analysis of nanoparticles and zinc content}

Morphological analysis of ZnONPs using TEM showed that they were near-spherical, rod shaped and hexagonal in shape (Fig. 1A). The Zn content significantly increased in representative root samples exposed to low $\left(50 \mathrm{mg} \mathrm{L}^{-1}\right)$, medium $\left(200 \mathrm{mg} \mathrm{L}^{-1}\right)$ and high (500 mg L L ${ }^{-1}$ concentrations of ZnONPs as compared to the control (Fig. 1B). Visualization of $\mathrm{Zn}$ in roots using Zinpyr-1 revealed accumulation of $\mathrm{Zn}$ in primary (Fig. 2, A-F) and lateral root tips (Fig. 2, H-J) as a result of exposure to $\mathrm{ZnONPs}$. However, in case of $\mathrm{Zn}$ ion treatment, Zynpyr-1 treatment showed translocation of $\mathrm{Zn}$ to the upper parts of the roots also (Fig. 2, K-M).

\section{Morphological measurements of seedlings}

The results showed no significant difference in shoot length when the seedlings were grown in the presence of 50-200 $\mathrm{mg} \mathrm{L}^{-1}$ of ZnONPs as compared to the control. However, the shoot growth significantly reduced after exposure to 400 and 500 $\mathrm{mg} \mathrm{L}^{-1}$ of ZnONPs. Exposure to all concentrations of ZnONPs significantly reduced the root length (Table 1).

\section{Measurement of $\mathrm{H}_{2} \mathrm{O}_{2}, M D A$ content and cell wall POD activity}

The $\mathrm{H}_{2} \mathrm{O}_{2}$ level did not show any significant increase at the lowest concentration of (50 $\mathrm{mg} \mathrm{L}^{-1}$ ) of $\mathrm{ZnONPs}$ exposure (Table 2 ). However, it was significantly increased as a result of exposure to $100-500 \mathrm{mg} \mathrm{L}^{-1}$ of ZnONPs (Table 2). The lipid peroxidation level was not modified when plantlets were exposed to 50 and $100 \mathrm{mg} / \mathrm{L}$ of 

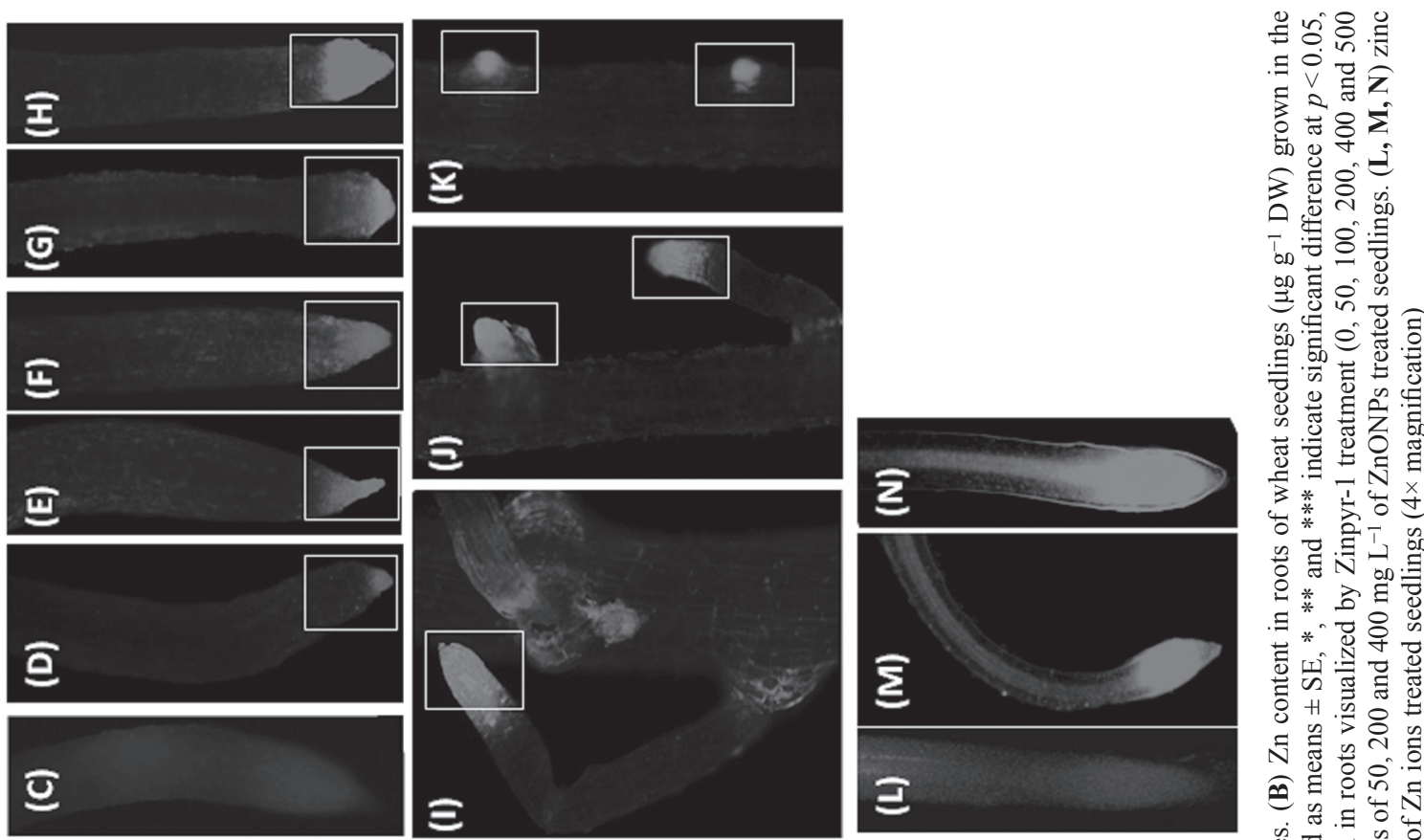

z
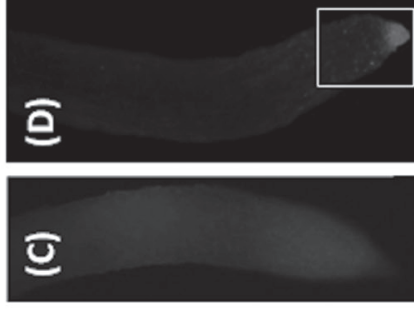

อ
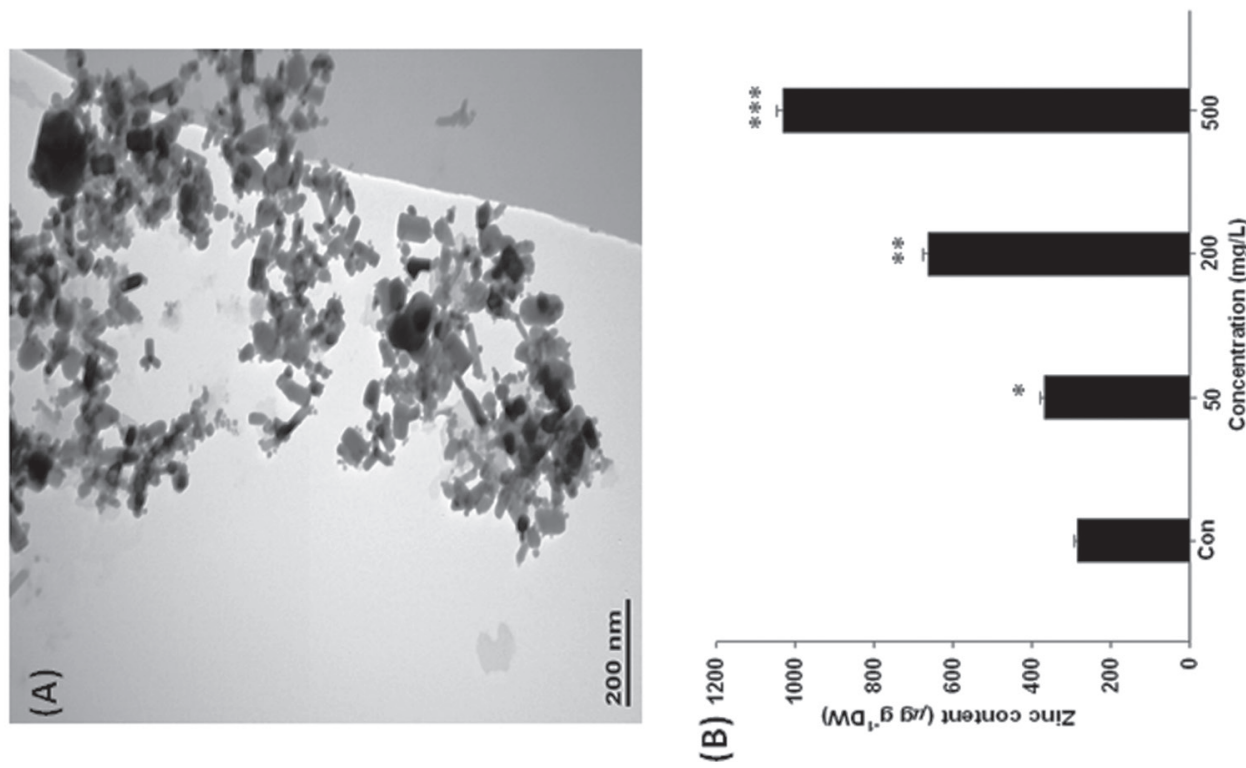

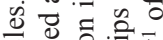

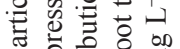

o

可氜

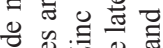

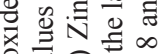

证国.

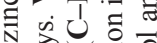

记宁焉

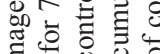

$\exists$ n 0 造

. 늘

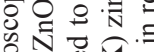

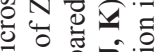

当

동

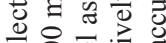

잉

을 च

政

छิ

牙 0

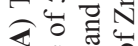

ङ

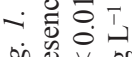

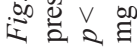



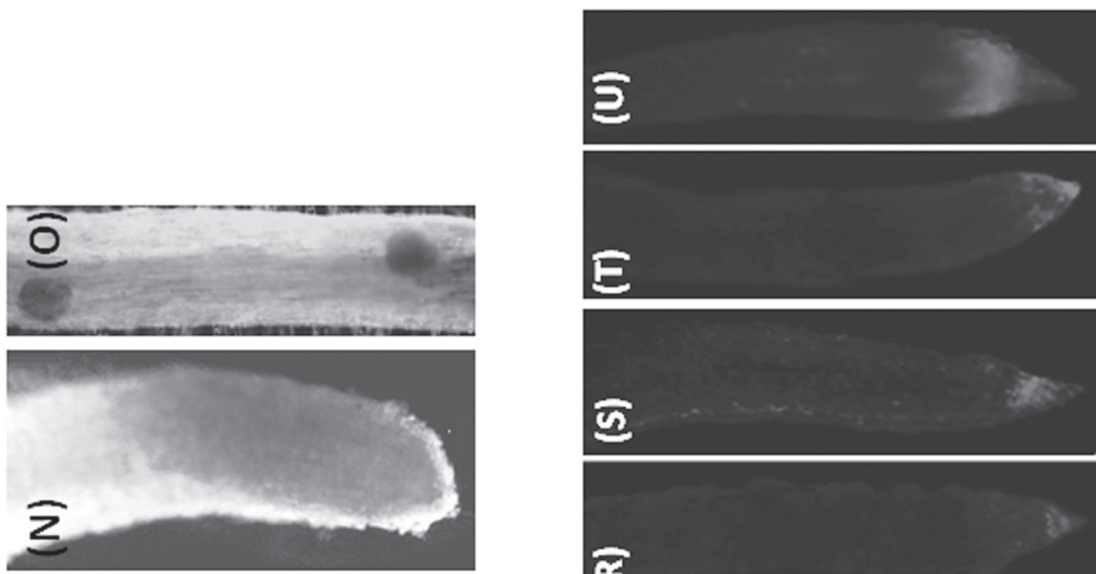

نั

요요

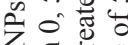

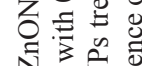
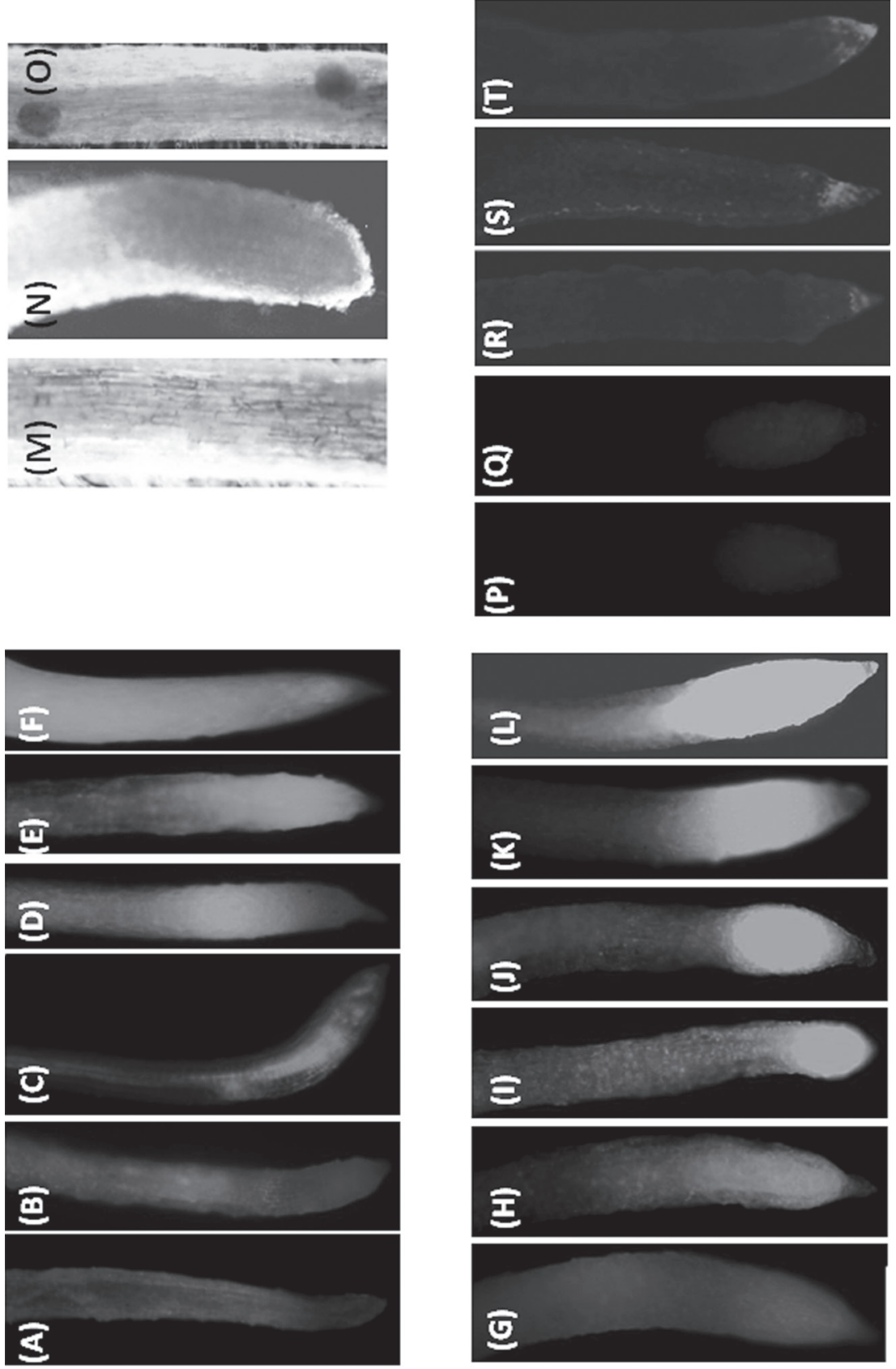

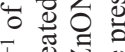

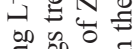

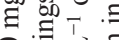

유류

坓 48

\&

8 \&

근

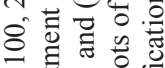

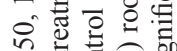

n.

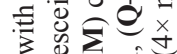

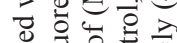

巴ँ

空

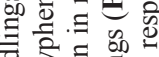

议

t

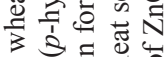

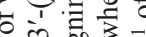

की

은

ヨี

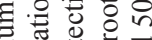

을

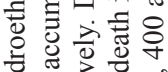

包 实

on

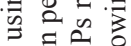

䆛云

은 의 에

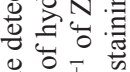

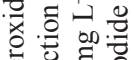

政

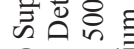

不语:

य包定

$i$ 定

is $\frac{0}{0} 80$

Acta Biologica Hungarica 67, 2016 
Table 1

Effect of different concentrations of zinc oxide nanoparticles on root and shoot growth of wheat seedlings

\begin{tabular}{|c|c|c|}
\hline $\begin{array}{c}\text { Concentration of ZnONPs } \\
\left(\mathrm{mg} \mathrm{L}^{-1}\right)\end{array}$ & Root length $(\mathrm{cm})$ & Shoot length $(\mathrm{cm})$ \\
\hline Control & $12.5 \pm 0.09$ & $14.23 \pm 0.12$ \\
\hline 50 & $8.12 \pm 0.12^{*}$ & $14.28 \pm 0.11$ \\
\hline 100 & $6.23 \pm 0.11^{* *}$ & $13.12 \pm 2.09$ \\
\hline 200 & $3.82 \pm 0.2^{* * *}$ & $12.29 \pm 2.07$ \\
\hline 400 & $1.82 \pm 0.05^{* * *}$ & $7.23 \pm 0.09^{*}$ \\
\hline 500 & $1.08 \pm 0.09^{* * *}$ & $5.98 \pm 0.03^{* *}$ \\
\hline
\end{tabular}

Values are expressed as means $\pm \mathrm{SE}, *, * *$ and $* * *$ indicate significant difference at $p<0.05, p<0.01$ and $p<0.001$ level as compared to the control.

Table 2

Effect of different concentrations of zinc oxide nanoparticles on hydrogen peroxide production, MDA level and root cell wall peroxidase activity in roots of wheat seedlings

\begin{tabular}{|c|c|c|c|}
\hline $\begin{array}{c}\text { Concentration of ZnONPs } \\
\left(\mathrm{mg} \mathrm{L}^{-1}\right)\end{array}$ & $\begin{array}{c}\mathrm{H}_{2} \mathrm{O}_{2} \\
\left(\mu \mathrm{mol} \mathrm{g}^{-1} \mathrm{DW}\right)\end{array}$ & $\begin{array}{c}\text { MDA } \\
\left(\mu \mathrm{mol} \mathrm{g} \mathrm{g}^{-1} \mathrm{DW}\right)\end{array}$ & $\begin{array}{c}\text { Cell wall peroxidase } \\
\left(\mathrm{U} \mathrm{mg}^{-1} \text { protein }\right)\end{array}$ \\
\hline Control & $62.98 \pm 0.59$ & $0.69 \pm 0.09$ & $4.28 \pm 1.12$ \\
\hline 50 & $69.59 \pm 1.88$ & $0.78 \pm 0.11$ & $4.12 \pm 1.18$ \\
\hline 100 & $112.53 \pm 0.89 * *$ & $0.81 \pm 0.74$ & $4.23 \pm 1.21$ \\
\hline 200 & $134.76 \pm 1.74 * *$ & $0.98 \pm 0.14^{*}$ & $4.02 \pm 1.14$ \\
\hline 400 & $163.56 \pm 1.47 * * *$ & $1.12 \pm 0.12 * *$ & $4.08 \pm 1.16$ \\
\hline 500 & $185.60 \pm 1.39 * * *$ & $1.39 \pm 0.09 * *$ & $6.11 \pm 1.18 *$ \\
\hline
\end{tabular}

Values are expressed as means $\pm \mathrm{SE}, *, * *$ and $* * *$ indicate significant difference at $p<0.05, p<0.01$ and $p<0.001$ level as compared to the control.

ZnONPs/L. However, the MDA levels in roots increased significantly after exposure to 200,400 and $500 \mathrm{mg} \mathrm{L}^{-1}$ of ZnONPs (Table 2). The cell wall-POD changed significantly only after exposure to $500 \mathrm{mg} \mathrm{L}^{-1}$ of ZnONPs (Table 2).

\section{Analysis of superoxide and $\mathrm{H}_{2} \mathrm{O}_{2}$ fluorescence in roots}

Detection of superoxide generation using the fluorescent probe DHE showed a concentration dependent increase in fluorescence levels in roots of wheat seedlings exposed to different concentrations of ZnONPs. The increase in DHE fluorescence levels was more obvious in the root tips (Fig. 2, Panel 1 A-F). As illustrated in 
Fig. A-F, an increase in $\mathrm{H}_{2} \mathrm{O}_{2}$ level was detected in roots after exposure to different concentrations of ZnONPs as evidenced by an increase in HPF fluorescence levels. The intensity of fluorescence was highest at the root tips.

\section{Root lignification and cell death}

Treatment with phloroglucinol-HCl showed no lignification in control roots (Fig. $2 \mathrm{M})$. However, lignification of root tissue highlighted by red coloration was observed in roots of seedlings exposed $500 \mathrm{mg} \mathrm{L}^{-1}$ of ZnONPs (Fig. 2. N-Q). Cytotoxicity analysis showed no cell death in roots of control and $50 \mathrm{mg} \mathrm{L}^{-1}$ of ZnONPs exposed wheat seedlings (Fig. 2, P-Q). However, loss of cell viability was detected in the root tips of wheat seedlings after exposure to $100-500 \mathrm{mg} \mathrm{L}^{-1}$ of ZnONPs (Fig. 2, R-U).

\section{DISCUSSION}

In the present study, it was observed that though the shoot had grown to a certain level, root elongation was suffered negatively as a result of exposure to ZnONPs. Though we tested two concentrations of soluble $\mathrm{Zn}$ ions (i.e. 8 and $12 \mathrm{mg} / \mathrm{L}$ ), no significant phytotoxic effect was observed. Both qualitative and quantitative analysis showed the presence of excess $\mathrm{Zn}$ in $\mathrm{ZnONPs}$ exposed wheat seedlings. In a recent study, Mukherjee et al. [23] has also reported that green pea plants grown in organic matter enriched soil treated with ZnONPs accumulated $\mathrm{Zn}$ in a concentrationdependent manner in roots. Treatment with the fluorescent probe Zinpyr-1 indicated that accumulation of $\mathrm{Zn}$ as a result of $\mathrm{ZnONPs}$ exposure was localized in the primary and lateral root tips of wheat seedlings. However, translocation of $\mathrm{Zn}$ to the upper parts of the roots, most probably through the vascular bundles, as evidenced by the Zynpyr-1 treatment in the vascular bundle area, was observed in roots of $\mathrm{Zn}$ ion treated seedlings. This strongly suggests that $\mathrm{Zn}$ accumulation was localized to the root tips of wheat seedlings as a result of ZnONPs treatment. Therefore, it could be assumed that, if the dissolution of $\mathrm{Zn}$ from ZnONPs was the cause of phytotoxicity in wheat seedlings, the $\mathrm{Zn}$ uptake would have increased the $\mathrm{Zn}$ content in upper parts of the root as a result of $\mathrm{ZnONPs}$ exposure just as in the case of $\mathrm{Zn}^{2+}$ treatments as suggested by Lin and Xing et al. [18] in ryegrass (Lolium perenne) seedlings. Therefore, as observed by Lin \& Xing [18] as in the case of ZnONPs treatment in rye seedlings, the phytotoxicity of ZnONPs in wheat seedlings was a result of their physical and chemical interferences with the root growth. Inhibition of root growth has also been observed in wheat seedlings when raised in a native, acid soil [32] and sand [8] impregnated with ZnONPs.

In this study, treatment with DHE and HPF also showed that the superoxide and $\mathrm{H}_{2} \mathrm{O}_{2}$ formation in roots was increased in roots treated with ZnONPs. Root growth inhibition and excess $\mathrm{H}_{2} \mathrm{O}_{2}$ accumulation has been reported from different plants 
under abiotic stress conditions $[9,17]$. The correlation between root growth retardation and $\mathrm{H}_{2} \mathrm{O}_{2}$ level as a result heavy metal stress has also been reported from different plants [26, 16]. Dimkpa et al. [8] has also reported that in wheat, the phytotoxicity of ZnONPs was associated with oxidative stress. Therefore, based on the results obtained it is clear that excess $\mathrm{H}_{2} \mathrm{O}_{2}$ generation as a result of ZnONPs exposure was one of the reasons for the root growth retardation in wheat seedlings. It has been known from earlier studies that, the redox status in the apical region of the root affects the root elongation in plants [7].

Several studies have been reported on lignin accumulation in plants under biotic, abiotic stresses $[6,29,31]$. Based on previous studies it has been known that excess formation of $\mathrm{H}_{2} \mathrm{O}_{2}$ will lead to activation of secondary defense responses in plants which will result in the lignification of cell walls, loss of cellular viability and growth [16]. Moreover, the lignification controls plant cell growth by promoting cell wall rigidity and has been correlated with decrease in growth of plant seedlings [20]. In this study, significant increase in cell wall bound POD activity was observed as a result of exposure to $500 \mathrm{mg} \mathrm{L}^{-1}$ of ZnONPs. Phloroglucinol- $\mathrm{HCl}$ staining also showed an increase in lignin accumulation at the highest concentration $\left(500 \mathrm{mg} \mathrm{L}^{-1}\right)$ of ZnONPs. Therefore, the increase in lignification as a result of ZnONPs in the presence of excess $\mathrm{H}_{2} \mathrm{O}_{2}$ points that lignification of cells was also responsible for the inhibition of root growth in wheat seedlings exposed to ZnONPs.

When ROS production exceeds the scavenging ability of a plant, oxidative damage can take place resulting in the degradation of cell membranes, nucleic acids and other cellular functions [1]. When the cellular ROS concentration increases due to the biotic and abiotic stresses, the balance of antioxidant defense systems and ROS generation get spoiled, then plants undergo an oxidative stress which causes lipid peroxidation, protein oxidation, enzyme inhibition, and nucleic acid damage leading to programmed cell death $[10,27,28]$. In this study, we detected an increase in PI fluorescence in root tips of ZnONPs exposed wheat seedlings. Previous studies demonstrated that $\mathrm{Zn}$ could form stable complexes with nucleic acids, affecting their stability and also cause genotoxicity in plants [30]. As reported by Finger-Teixeira et al. [9], the reduction of root growth as observed in this study might also be linked to significant loss of cell viability in wheat seedlings.

\section{CONCLUSIONS}

On the basis of the results obtained in the present investigation and based on previous reports, it could be concluded that the enhanced generation of $\mathrm{H}_{2} \mathrm{O}_{2}$, lignification and cell death might be responsible for the inhibition of root growth in wheat seedlings under $\mathrm{ZnONPs}$ treatment. Therefore, care must be taken to protect the food crops from potential toxic effects of ZnONPs though their accidental release to the agricultural fields. 


\section{ACKNOWLEDGEMENTS}

This paper was supported by the KU Research Professor Program of Konkuk University, Seoul, South Korea.

\section{REFERENCES}

1. Asada, K. (2006) Production and scavenging of reactive oxygen species in chloroplasts and their functions. Plant Physiol.141, 391-396.

2. Asztemborska, M., Steborowski, R., Kowalska, J., Bystrzejewska-Piotrowska, G. (2015) Accumulation of aluminium by plants exposed to nano and microsized particles of $\mathrm{Al}_{2} \mathrm{O}_{3}$. Int. J. Environ. Res. 9 , 109-116.

3. Brennan, T., Frenkel, C. (1977) Involvement of hydrogen peroxide in regulation of senescence in pear. Plant Physiol. 59, 411-416.

4. Broadley, M. R., White, P. J., Hammond, J. P., Zelko, I., Lux, A. (2007) Zinc in plants. N. Phytol. 173, 677-702.

5. Bystrzejewska-Piotrowska, G., Golimowski, J., Urban, P. L. (2009) Nanoparticles: their potential toxicity, waste and environmental management. Waste Manag. 29, 2587-259.

6. Canõ-Delgado, A., Penfield, S., Smith, C., Catley, M., Bevan, M. (2003) Reduced cellulose synthesis invokes lignifications and defense responses in Arabidopsis thaliana. Plant J. 34, 351-362.

7. Córdoba-Pedregosa, M. C., Córdoba, F., Villalba, J. M., González-Reyes, J. M. (2005) Changes in intracellular and apoplastic peroxidase activity, ascorbate redox status, and root elongation induced by enhanced ascorbate content in Allium cepa L. J. Exp. Bot. 56, 685-694.

8. Dimkpa, C. O., McLean, J. E., Latta, D. E., Manangón, E., Britt, D. W., Johnson, W. P., Boyanov, M. I., Anderson, A. J. (2012) $\mathrm{CuO}$ and $\mathrm{ZnO}$ nanoparticles: phytotoxicity, metal speciation and induction of oxidative stress in sand-grown wheat. J. Nanopart. Res. 14, 1125-1129.

9. Finger-Teixeira, A., Ferrarese, M. L. L., Soares, A. R., daSilva, D., Ferrarese-Filho, O. (2010) Cadmium-induced lignifications restricts soybean root growth. Ecotoxicol. Environ. Saf. 73, 19591964.

10. Halliwell, B., Gutteridge, J. M. C. (1999) The chemistry of free radicals and related 'reactive species'. Free Radic. Biol. Med. 3, 220.

11. Handy, R. D., Owen, R., Valsami-Jones, E. (2008) The ecotoxicology of nanoparticles and nanomaterials: current status, knowledge gaps, challenges, and future needs. Ecotoxicol. 17, 315-325.

12. Heath, R. L., Packer, L. (1968) Photoperoxidation in isolated chloroplasts. I. Kinetics and stoichiometry of fatty acid peroxidation. Arch. Biochem. Biophy. 125, 189-198.

13. Kolbert, Z. S., Pető, A., Lehotai, N., Feigl, G., Ördög, A., Erdei, L. (2012) In vivo and in vitro studies on fluorophore-specificity. Acta Biol. Szeged 56, 37-41.

14. Kwasniewskia, M., Chwialkowska, K., Kwasniewska, J., Kusak, J., Siwinski, K., Szarejko, I. (2013) Accumulation of peroxidase related reactive oxygen species in trichoblasts correlates with root hair initiation in barley. J. Plant Physiol. 170,185-195.

15. Kwon, Y. I., Abe, K., Endo, M., Osakabe, K., Ohtsuki, N., Nishizawa-Yoko, A., Tagiri, A., Saika, H., Toki, S. (2013) DNA replication arrest leads to enhanced homologous recombination and cell death in meristems of rice OsRecQl4 mutants. BMC Plant Biol. 13, 62-75.

16. Li, X. N., Ma, H. Z., Jia, P. X., Wang, J., Jia, L. Y., Zhang, T. G., Yang, Y. L., Chen, H. J., Wei, X. (2012) Responses of seedling growth and antioxidant activity to excess iron and copper in Triticum aestivum L. Ecotoxicol. Environ. Saf. 86, 47-53.

17. Lin, C. C., Kao, C. H. (2001) Cell wall peroxidase activity, hydrogen peroxide level and NaClinhibited root growth of rice seedlings. Plant Soil 230, 135-143.

18. Lin, D., Xing, B. (2008) Root uptake and phytotoxicity of ZnO nanoparticles. Environ. Sci. Technol. $42,5580-5585$. 
19. Love, S. A., Maurer-Jones, M. A., Thompson, J. W., Lin, Y. S., Haynes, C. L. (2012) Assessing nanoparticle toxicity. Annu. Rev. Anal. Chem. 5, 181-205.

20. Lybeer, B., Koch, G., VanAcker, J., Goetghebeur, P. (2006) Lignification and cell wall thickening in nodes of Phyllostachys viridiglaucescens and Phyllostachys nigra. Ann. Bot. 97, 529-539.

21. Ma, H., Williams, P. L., Diamond, S. A. (2013) Ecotoxicity of manufactured ZnO nanoparticles - A review. Environ. Pol. 172, 76-85.

22. Miralles, P., Church, T. L., Harris, A. T. (2012) Toxicity, uptake, and translocation of engineered nanomaterials in vascular plants. Environ. Sci. Technol. 46, 9224-9239.

23. Mukherjee, A., Peralta-Videa, J. R., Bandyopadhyay, S., Rico, C. M., Zhao, L., Gardea-Torresdey, J. L. (2014) Physiological effects of nanoparticulate $\mathrm{ZnO}$ in green peas (Pisum sativum L.) cultivated in soil. Metallomics 6, 132-138.

24. Munzuroglu, O., Geckil, H. (2002) Effects of metals on seed germination, root elongation, and coleoptile and hypocotyl growth in Triticum aestivum and Cucumis sativus. Arch. Environ. Contam. Toxicol. 43, 203-213.

25. Rogers, L. A., Dubos, C., Surman, C., Willment, J., Cullis, I. F., Mansfield, S. D., Campbell, M. M. (2005) Comparison of lignin deposition in three ectopic lignification mutants. New Phytol. 168, $123-140$.

26. Ruley, A. T., Sharma, N. C., Sahi, S. V. (2004) Antioxidant defense in a lead accumulating plant, Sesbania drummondii. Plant Physiol. Biochem. 42, 899-906.

27. Sharma, P., Bhatt, D., Zaidi, M. G., Pardha Saradhi, P., Khanna, P. K., Arora, S. (2012) Silver nanoparticle-mediated enhancement in growth and antioxidant status of Brassica juncea. Appl. Biochem. Biotechnol. 167, 2225-2233.

28. Smirnoff, N. (1993) The role of active oxygen in the response of plants to water deficit and desiccation. New Phytol. 125, 27-58.

29. Tronchet, M., Balagué, C., Kroj, T., Jouanin, L., Roby, D. (2010) Cinnamyl alcohol dehydrogenases $\mathrm{C}$ and D, key enzymes in lignin biosynthesis, play an essential role in disease resistance in Arabidopsis. Mol. Plant Pathol. 11, 83-92.

30. Truta, E. C., Gherghe, D. N., Bara, I. C. I., Vochita, G. V. (2013) Zinc induced genotoxic effects in root meristems of Barley seedlings. Not Bot. Horti. Agrobo. 41, 150-156.

31. Vardar, F., İsmailoğlu, I., İnan, D., Ünal, M. (2011) Determination of stress responses induced by aluminum in maize (Zea mays). Acta Biol. Hung. 62, 156-170.

32. Watson, J. L., Fang, T., Dimkpa, C. O., Britt, D. W., McLean, J. E., Jacobson, A., Anderson, A.J. (2015) The phytotoxicity of $\mathrm{ZnO}$ nanoparticles on wheat varies with soil properties. Biometals 28 , 101-112.

33. Song, W. Y., Choi, K. M., Kim, D. Y., Geisler, M., Park, J., Vincenzetti, V., Schellenberg, M., Kim, S. A., Lim, Y. P., Noh, E. W., Lee, Y., Martinoia, W. (2010) Arabidopsis PCR2 is a zinc exporter involved in both zinc extrusion and long-distance zinc transport. The Plant Cell 22, 2237-2252.

34. Yanık, F., Vardar, F. (2015) Toxic effects of aluminum oxide $\left(\mathrm{Al}_{2} \mathrm{O}_{3}\right)$ nanoparticles on root growth and development in Triticum aestivum. Water Air Soil Pollut. 226, 296. 